\title{
Low humic acids promote in vitro lily bulblet enlargement by enhancing roots growth and carbohydrate metabolism*\#
}

\author{
Yun $\mathrm{WU}^{1}$, Yi-ping XIA ${ }^{\dagger+1}$, Jia-ping ZHANG ${ }^{1}$, Fang $\mathrm{DU}^{1,2}$, Lin ZHANG ${ }^{1}$, Yi-di MA ${ }^{1}$, Hong ZHOU ${ }^{1}$ \\ $\left({ }^{I}\right.$ Department of Horticulture, College of Agriculture and Biotechnology, Zhejiang University, Hangzhou 310058, China) \\ $\left({ }^{2}\right.$ College of Horticulture, Shanxi Agricultural University, Taigu 030800, China $)$ \\ †E-mail: ypxia@zju.edu.cn
}

Received May 16, 2016; Revision accepted July 13, 2016; Crosschecked Oct. 18, 2016

\begin{abstract}
Bulblet development is a problem in global lily bulb production and carbohydrate metabolism is a crucial factor. Micropropagation acts as an efficient substitute for faster propagation and can provide a controllable condition to explore bulb growth. The present study was conducted to investigate the effects of humic acid (HA) on bulblet swelling and the carbohydrate metabolic pathway in Lilium Oriental Hybrids 'Sorbonne' under in vitro conditions. HA greatly promoted bulblet growth at $0.2,2.0$, and $20.0 \mathrm{mg} / \mathrm{L}$, and pronounced increases in bulblet sucrose, total soluble sugar, and starch content were observed for higher HA concentrations ( $\geq 2.0 \mathrm{mg} / \mathrm{L})$ within $45 \mathrm{~d}$ after transplanting (DAT). The activities of three major starch synthetic enzymes (including adenosine 5'-diphosphate glucose pyrophosphorylase, granule-bound starch synthase, and soluble starch synthase) were enhanced dramatically after HA application especially low concentration HA (LHA), indicating a quick response of starch metabolism. However, higher doses of HA also caused excessive aboveground biomass accumulation and inhibited root growth. Accordingly, an earlier carbon starvation emerged by observing evident starch degradation. Relative bulblet weight gradually decreased with increased HA doses and thereby broke the balance between the source and sink. A low HA concentration at $0.2 \mathrm{mg} / \mathrm{L}$ performed best in both root and bulblet growth. The number of roots and root length peaked at 14.5 and $5.75 \mathrm{~cm}$, respectively. The fresh bulblet weight and diameter reached $468 \mathrm{mg} \mathrm{(2.9} \mathrm{times} \mathrm{that} \mathrm{under} \mathrm{the} \mathrm{control} \mathrm{treatment)} \mathrm{and}$ $11.68 \mathrm{~mm}$, respectively. Further, sucrose/starch utilization and conversion were accelerated and carbon famine was delayed as a result with an average relative bulblet weight of $80.09 \%$. To our knowledge, this is the first HA application and mechanism research into starch metabolism in both in vitro and in vivo condition in bulbous crops.
\end{abstract}

Key words: Bulblet development, Humic acid, Starch metabolism, Source-sink conversion, Lilium Oriental Hybrids 'Sorbonne'

http://dx.doi.org/10.1631/jzus.B1600231

CLC number: $5682.2+9$

\section{Introduction}

Flower bulbs represent a significant segment of the global floriculture industry, and have a variety of

\footnotetext{
Corresponding author

* Project supported by the National High-Tech R \& D Program (863) of China (No. 2011AA100208) and the Zhejiang Provincial Natural Science Foundation of China (No. LY12C15003)

${ }^{\#}$ Electronic supplementary materials: The online version of this article (http://dx.doi.org/10.1631/jzus.B1600231) contains supplementary materials, which are available to authorized users (iD) ORCID: Yun WU, http://orcid.org/0000-0002-1612-5620 (C) Zhejiang University and Springer-Verlag Berlin Heidelberg 2016
}

ornamental uses (Benschop et al., 2010). Unfortunately, due to low natural bulb multiplication rates or long juvenile phases, commercial release of a new genotype may take 10 or even 20 years by conventional vegetative propagation methods (de Klerk, 2012). A bulb is the core center of bulbous plants, and the specialized scales (modified petioles) can serve as the carbon store during the early developmental stage, providing the plants with carbon skeleton and energy for reproductive growth, then inflorescence formation and blooming, and completing their life cycle (Fig. 1 takes the lily as an example). Additionally, a larger 

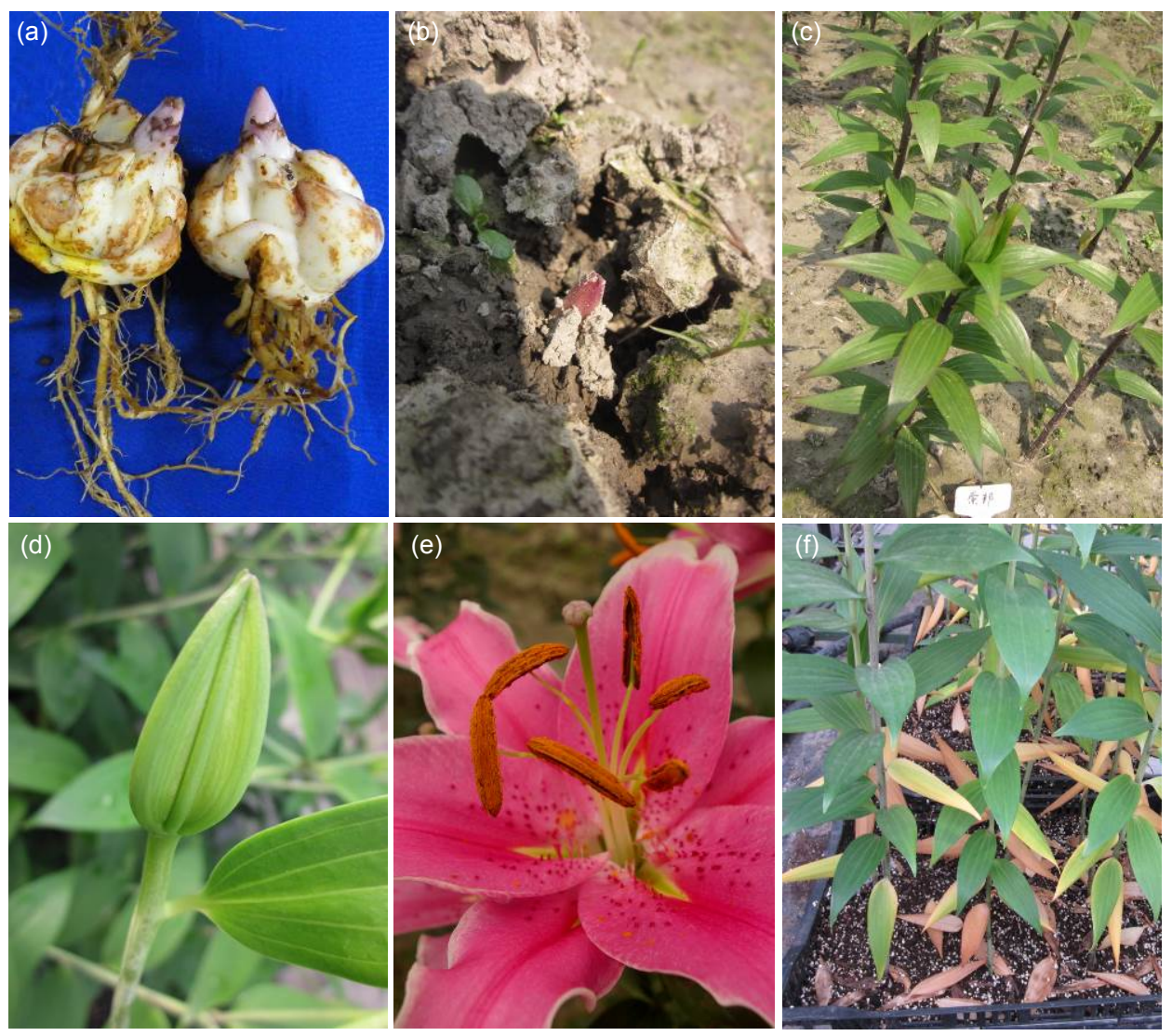

Fig. 1 Whole life cycle of commercial lily cultivar Lilium Oriental Hybrids 'Sorbonne' in Zhejiang Province

(a) Bulb (modified petioles, white part) with bud (the light pink part) dormancy release; (b) Sprout after planting; (c) Vegetative growth; (d) Immature flower bud; (e) Pink and fragrant flower; (f) Plant after blossom (Note: for interpretation of the references to color in this figure legend, the reader is referred to the web version of this article)

bulb usually produces more vigorous plants with higher flower quality (Chen et al., 2000). Speeding up the propagation cycle converts into the question of how to shorten the bulb development process and obtain a larger storage organ.

Micropropagation is a sine qua non for breeding in the present-day because of faster propagation rates in vitro, e.g., newly bred cultivars can now be introduced onto the market within 7-8 years for the lily (de Klerk, 2012), and offers many other advantages (Podwyszyńska, 2012). However, for most major bulbous crops, the protocols are still not workable for commercial use because of low propagation rates even in vitro. Plant growth regulators (PGRs) are involved in nearly all aspects of plant growth and development including in vitro storage organ formation of ornamental geophytes (Ascough et al., 2008). Although many artificial PGRs have been applied successfully in bulbous crops in vitro (Gerrits and de Klerk, 1992; Marinangeli and Curvetto, 1997;
Kumar et al., 2005; Jásik and de Klerk, 2006), almost all reports focused only on optimization of culture conditions and work on the related bulblet growth mechanism is scarce. Among these PGRs, humic acids (HAs), complicated mixtures of biologically transformed organic debris (Hayes and Clapp, 2001), proved to be beneficial to plant growth and productivity by influencing, directly or indirectly, several plant biochemical processes (Zandonadi et al., 2007). One aspect is to promote root development to be advantageous for nutrition uptake (Canellas et al., 2002; Zandonadi et al., 2007). Fulvic acid increased the extra-large tubers by being sprayed on the leaves of potato plants (Suh et al., 2014). Argüello et al. (2006) also found that the use of vermicompost as a substrate caused early bulbing and lengthened the bulb filling period in garlic. To our knowledge, there are no reports on HA application focusing on the effects on bulb formation and development in bulbous plants. We have previously shown that HAs can 
enhance plant growth and root development in the Oriental lily under open fields (Chang et al., 2012). Thereby, we hypothesize that HAs can be beneficial to bulblet swelling in vitro.

Bulblet formation and development (also called tuberization) is a highly coordinated morphophysiological process under the influence of both extrinsic and intrinsic factors (Podwyszyńska, 2012). Generally, large amounts of carbohydrates accumulate during bulb formation (Kawa and de Hertogh, 1992), e.g., starch constitutes the dominant storage reserve polysaccharide (about $20 \%-30 \%$ fresh weight $(\mathrm{FW})$ ). Starch, comprised of amylase and amylopectin, is an insoluble polyglucan produced by starch synthase (SS) using adenosine 5'-diphosphate glucose (ADPG) as the sugar donor molecule (Bahaji et al., 2014). Granule-bound starch synthase (GBSS) can specifically elongate amylose (Nelson and Rines, 1962) while soluble starch synthase (SSS) is exclusively involved in amylopectin biosynthesis (Streb and Zeeman, 2012). We have previously reported that bulb formation and swelling are closely correlated with carbohydrates manipulation between aboveground and underground parts either in the lily or Lycoris under open field conditions (Zheng et al., 2011; 2012; Chang et al., 2013; She et al., 2014). Comparative carbohydrate-related genes involved in bulblet formation and development were examined in Lilium davidii var. unicolor very recently demonstrating the fundamental role of carbohydrate metabolism, especially starch and sucrose metabolism, in lily bulblet emergence and development at the transcriptional level (Li et al., 2014). The main aspects of bulb development can be agreed upon as they relate to the starch metabolic pathway. Leaves can fix carbon during the day and then remobilize the carbohydrates during the subsequent night to support photosynthetic metabolism and growth. Therefore, leaves are regarded as photosynthetic tissues whilst storage organs, e.g., bulbs, are heterotrophic organs (Bahaji et al., 2014). Source-sink changes constantly in the lily plant (Wu et al., 2012) and intensification of sink and source performances could enhance the yield of the storage organ, e.g., potato (Katoh et al., 2015). Fig. S1 shows the classical starch metabolism and conversion model within whole flower bulbs.

In the current paper we selected Lilium as our model material for its high reproductive efficiency compared with the tulip or Lycoris (Alderson et al., 1982; Kuijpers and Langens-Gerrits, 1997; Chang et al., 2013). We focused solely on starch metabolism linked to autotrophic organ carbon reserve conversion. Principal carbohydrates and starch enzymes involved in this pathway were examined for different levels of HA treatment or non-HA treatment during in vitro bulblet swelling. Thus, our research can provide a fundamental theory for HA usage and for shortening bulbous plants' breeding programme. So far, this is the first application of HA in a scheme for mass propagation of not only lily but also all bulbous crops.

\section{Materials and methods}

\subsection{Plant materials}

'Sorbonne' lily bulbs (16 to $18 \mathrm{~cm}$ in circumference) were collected from a commercial supplier (Zhejiang Hongyue Seed Co., Ltd., China) imported from the Netherlands on September 10, 2011. The lily bulbs were immediately repacked into a plastic bag with tiny holes for cold storage in a refrigerator $\left(4{ }^{\circ} \mathrm{C}\right)$ for 2 to 3 weeks before tissue culture. Individual shoots (shoot length $1-2 \mathrm{~cm}$, basal diameter 3-5 mm) were obtained from induction culture for further use. The plantlets were illuminated with a $12 \mathrm{~h} / 12 \mathrm{~h}$ photoperiod $\left(60 \mu \mathrm{mol} /\left(\mathrm{m}^{2} \cdot \mathrm{s}\right)\right.$ cool white fluorescent irradiance) at $(24 \pm 2){ }^{\circ} \mathrm{C}$ in all experiments at the Physiology \& Molecular Biology Laboratory of Ornamental Plants and Tissue Culture Laboratory of Ornamental Plants in Zijingang Campus, Zhejiang University, China (E $120^{\circ} 11^{\prime}$, N $30^{\circ} 29^{\prime}$ ) unless indicated otherwise.

\subsection{Humic acid treatments and morphological observation}

In total, there were four treatments, the basal MS (Murashige and Skoog, 1962) medium plus $8 \mathrm{~g} / \mathrm{L}$ agar and $70 \mathrm{~g} / \mathrm{L}$ sucrose as the control $(\mathrm{CON})$ and the control medium containing different concentrations of HA (Aladdin ${ }^{\circledR}$, fulvic acid $\geq 90 \%, \mathrm{H} 108498$, China) doses, the low concentration HA (LHA), moderate concentration HA (MHA), and high concentration HA (HHA), with the values of $0.2,2.0$, and $20.0 \mathrm{mg} / \mathrm{L}$, respectively. The HA was directly added to the medium prior to autoclaving. Each glass conical flask ( $6.5 \mathrm{~cm}$ diameter $\times 10 \mathrm{~cm}$ height, Shuniu, China) was 
planted with five sterile shoots, and a total of 200 shoots were initially used for each treatment. We harvested and observed the plantlets every $15 \mathrm{~d}$ until the materials were exhausted. The specific sampling dates were as follows: February 2, February 17, March 4, March 19, and April 3 in 2013 at 9:00 a.m. (Beijing Time) each day. We defined these harvesting time points as DAT15, DAT30, DAT45, DAT60, and DAT75, respectively. DAT was short for days after transplanting.

Seven morphological indices were observed to evaluate in vitro bulblet growth: plantlet height, number of leaves, number of roots, root length, fresh bulblet weight, fresh plantlet weight, and bulblet diameter (Canellas et al., 2002; Zheng et al., 2012). The fresh bulblet weight was estimated using an electronic balance (Mettler Toledo, PL202-L, Switzerland). The bulblet diameter was detected using an electronic digital vernier calliper (Links, China) and was only recorded at DAT60 and later time points. Ten independent plantlets were randomly selected for measurement of the above listed traits. Then the bulblets were thoroughly washed using distilled deionized (dd) water and frozen in liquid nitrogen ( $\geq 30 \mathrm{~min}$ ), and stored at $-75^{\circ} \mathrm{C}$ for determination of major starch metabolic pathway traits.

\subsection{Measurements of carbohydrate content and enzyme activity levels}

First, the concentrations of major carbohydrates including starch, sucrose, and total soluble sucrose were measured by modified anthrone colourimetry, as described by McCready et al. (1950) and in our lab (Zheng et al., 2012), and $0.5 \mathrm{~g}$ of tissue was used for each sample. The absorbance was determined at $620 \mathrm{~nm}$.

For the assays of key enzymes in starch metabolism, $1 \mathrm{~g}$ frozen bulblet powder was taken and ground in liquid nitrogen with $5 \mathrm{ml}$ enzyme extracting buffer $(100 \mathrm{mmol} / \mathrm{L}$ Tricine- $\mathrm{NaOH}(\mathrm{pH} 7.5)$, $8 \mathrm{mmol} / \mathrm{L} \mathrm{MgCl}_{2}, 2 \mathrm{mmol} / \mathrm{L}$ ethylenediaminetetraacetic acid (EDTA), $50 \mathrm{mmol} / \mathrm{L}$ 2-mercaptoethanol, $12.5 \%(\mathrm{v} / \mathrm{v})$ glycerol, and $1 \%(0.01 \mathrm{~g} / \mathrm{ml})$ insoluble polyvinylpyrrolidone-40). The homogenate was then centrifuged at $30000 \mathrm{~g}$ for $30 \mathrm{~min}$, and the resulting supernatant was used as the preparation of ADPG pyrophosphorylase (AGPase, EC 2.7.7.27) and SSS (EC 2.4.1.21) while sediment was used for GBSS (EC 2.4.1.21). Reagents were purchased from Sigma-
Aldrich (St. Louis, USA). All assays were carried out at $30^{\circ} \mathrm{C}$ in the various reaction mixtures described as follows.

The AGPase assay was conducted in $100 \mathrm{mmol} / \mathrm{L}$ HEPES-NaOH $(\mathrm{pH}=7.4), 1.2 \mathrm{~mol} / \mathrm{L}$ ADP-glucose, $3 \mathrm{~mol} / \mathrm{L}$ inorganic pyrophosphoric acid (PPi), $5 \mathrm{mmol} / \mathrm{L}$ $\mathrm{MgCl}_{2}, 4 \mathrm{~mol} / \mathrm{L}$ dithiothreitol (DTT), and enzyme preparation was in a reaction mixture of $130 \mu \mathrm{l}$. After $20 \mathrm{~min}$, the reaction was terminated by heating the mixture in boiling water for $30 \mathrm{~s}$. The resulting solution was transferred to a $1.5-\mathrm{ml}$ Eppendorf tube and centrifuged at $10000 \mathrm{~g}$ for $10 \mathrm{~min}$. A portion $(100 \mu \mathrm{l})$ of the supernatant was taken and mixed with $5.2 \mu \mathrm{l}$ colorimetric solution $(5.76 \mathrm{~mol} / \mathrm{L}$ nicotinamide adenine dinucleotide phosphate (NADP), $0.08 \mathrm{U}$ phospho (P)-gucomutase, $0.07 \mathrm{U}$ glucose-6-phosphate (G6P)dehydrogenase). The activity was determined by measuring the increase in absorbance at $340 \mathrm{~nm}$.

The SSS assay was conducted in $50 \mathrm{mmol} / \mathrm{L}$ HEPES-NaOH (pH=7.4), $1.6 \mathrm{~mol} / \mathrm{L}$ ADPG, $0.7 \mathrm{mg}$ amylopectin, and $15 \mathrm{mmol} / \mathrm{L}$ DTT, and enzyme preparation was in a reaction mixture of $56 \mu$. Twenty minutes later, the enzyme was inactivated by placing the mixture in a boiling-water bath for $30 \mathrm{~s}$ and was immediately cooled on ice for $20 \mathrm{~s}$. Then the mixture was added to by $20 \mu \mathrm{l}$ of a solution of $50 \mathrm{mmol} / \mathrm{L}$ HEPES-NaOH $(\mathrm{pH}=7.4), 4 \mathrm{~mol} / \mathrm{L}$ phosphoenolpyruvate (PEP), $200 \mathrm{~mol} / \mathrm{L} \mathrm{KCl}$, and $10 \mathrm{mmol} / \mathrm{L} \mathrm{MgCl}_{2}$, and pyruvate kinase $(1.2 \mathrm{U})$, and incubated for $30 \mathrm{~min}$ at $30^{\circ} \mathrm{C}$ in a water bath. The resulting solution was heated in boiling water for $30 \mathrm{~s}$ and then subjected to centrifugation at $10000 \mathrm{~g}$ for $10 \mathrm{~min}$. The supernatant $(60 \mu \mathrm{l})$ was mixed with a solution of $50 \mathrm{mmol} / \mathrm{L}$ HEPES-NaOH (pH=7.4), $10 \mathrm{~mol} / \mathrm{L}$ glucose, $20 \mathrm{mmol} / \mathrm{L} \mathrm{MgCl}_{2}, 2 \mathrm{mmol} / \mathrm{L} \mathrm{NADP}$, and pyruvate kinase $(1.2 \mathrm{U}), 1.4 \mathrm{U}$ hexokinase, and $0.35 \mathrm{U}$ G6P-dehydrogenase. The enzymatic activity was measured as the increase in absorbance at $340 \mathrm{~nm}$.

The sediment was washed four times using $1 \mathrm{ml}$ of the enzyme extracting buffer mentioned previously, and was detected using the same method as SSS. The whole enzyme estimation methods were slightly modified according to Nakamura et al. (1989).

The enzymes were compared on the basis of soluble protein content, and we used a modified Bradford method to determine the soluble protein (Bradford, 1976). Final concentrations in the solution were $0.01 \%(1 \mathrm{~g} / \mathrm{L})$ Coomassie Brilliant Blue G-250 
(Ourchem $^{\circledR}, 71011284$, Sinopharm, China), 4.7\% $(0.047 \mathrm{~g} / \mathrm{ml})$ ethanol, and $8.5 \%(0.085 \mathrm{~g} / \mathrm{ml})$ phosphoric acid. Bulblet tissue $(0.5 \mathrm{~g})$ was ground with $5 \mathrm{ml}$ distilled water and diluted to $10 \mathrm{ml}$. The homogenates were centrifuged at $10000 \mathrm{r} / \mathrm{min}$ at $4{ }^{\circ} \mathrm{C}$ for $20 \mathrm{~min}$. We used $20 \mu \mathrm{l}$ supernate $+80 \mu \mathrm{l}$ distill water $+5 \mathrm{ml}$ solution, standing for $3 \mathrm{~min}$. Absorbance at $595 \mathrm{~nm}$ was measured.

All the final samples $(200 \mu \mathrm{l})$ were arranged in a 96-well enzyme label plate (Costar, 3590, USA) and spectrophotometric analysis was conducted on a Multilabel Reader (Perkin Elmer Corporation, Enspire $^{\mathrm{TM}}$ 2300, USA). All treatment experiments consisted of three independent replicates.

\subsection{Statistics}

Data were statistically analysed using analysis of variance (ANOVA) by SPSS Version 13.0 software and tested for significant $(P<0.05)$ treatment differences using the Duncan test. Bulblet fresh weight was also determined as a percentage of plantlet fresh weight (relative bulblet weight, RBW) (Gerrits and de Klerk, 1992). The radius $(r)$ was derived from the diameter of the bulblets. Putting the value of $r$ in the formula $4 / 3 \pi r^{3}$, the volume of the bulblet was calculated (Thakur et al., 2006). Bulblet swelling rate $(\mathrm{mg} /($ plantlet $\cdot \mathrm{d}))=\left(\right.$ bulblet fresh weight ${ }_{\mathrm{DAT}((1+N) \times 15)^{-}}$ bulblet fresh weight $\left.{ }_{\mathrm{DAT}(N \times 15))}\right)$ interval $(15 \mathrm{~d})(N=1,2$, 3, 4) (Wang et al., 2008). Starch accumulation rate $=$ (starch content $t_{\mathrm{DAT}((1+N) \times 15)}$-starch content DAT $\left.(N \times 15)\right) /$

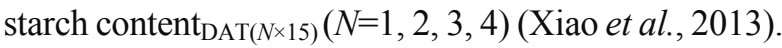

\section{Results}

\subsection{Effects of non-HA and HA treatments on morphological traits of lily plantlets in vitro}

The shoots were transplanted evenly with exogenous application of HA, and we considered seven critical morphological parameters and two derived indices to investigate the positive and/or negative effectiveness under HA treatments (Fig. 2). A quick response after HA treatments could be observed just at DAT15 (Table 1), and almost all the biomass indexes including plantlet height, number of leaves, number of roots, and root length increased significantly during the incipient bulblet stage. Thereafter, these traits were maintained at a relatively high level.
In comparison, the controls changed stably (Table 1). It was noticeable to see that for plantlet height, MHA showed the lowest value $(1.56 \mathrm{~cm})$ at DAT15 while it increased dramatically to its highest at a later stage, e.g., $5.21 \mathrm{~cm}$ at DAT60. The number of leaves for LHA, MHA, and HHA was $7.7 \%$ to $38.5 \%$ higher than that of the control at DAT15, implying a possible stronger photosynthetic capacity. The number of leaves in MHA showed a similar trend as the plantlet height, viz., low at the beginning stage (2.8 at DAT15) but high at later stages (4.1 at DAT45). Taking both plantlet height and number of leaves together as major aboveground morphological traits, it can be concluded that for higher HA application, it caused relative vigorous aboveground growth at different phases (Table 1).

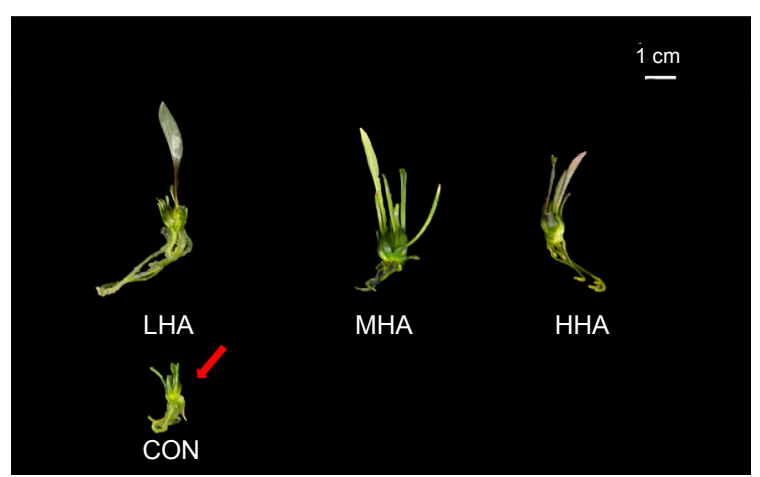

Fig. 2 Growth of control and HA application of in vitro Lilium Oriental Hybrids 'Sorbonne'

LHA: low concentration HA; MHA: moderate concentration HA; HHA: high concentration HA; CON: control. Bulblets were taken at DAT60. Arrow means the bulblet part

The number of roots during the former two stages for LHA was much greater than that of the control but not to a significant level (Table 1). Higher HA treatments $(\geq 2.0 \mathrm{mg} / \mathrm{L})$ only showed a slight superiority than the control until DAT45. Nevertheless, the average root length did not differ significantly between HA treatments and non-HA treatment, and the values for MHA and HHA were lower than that for the control. Despite the total fresh plantlet weight for HA ones all markedly exceeding that for the control, yet with respect to the bulblet weight there was only a smaller increase. This was also confirmed by relative bulblet weight. Accordingly, the RBW for LHA showed a range between $76.69 \%$ and $84.46 \%$, whereas the average RBWs for MHA and 
Table 1 Effects of humic acid (HA) treatments on morphological changes during Lilium Oriental Hybrids 'Sorbonne' plantlet development in vitro

\begin{tabular}{|c|c|c|c|c|c|c|c|c|}
\hline \multirow{2}{*}{ Time } & \multicolumn{4}{|c|}{ Plantlet height $(\mathrm{cm})$} & \multicolumn{4}{|c|}{ Number of leaves } \\
\hline & LHA & MHA & HHA & $\mathrm{CON}$ & LHA & MHA & HHA & $\mathrm{CON}$ \\
\hline DAT15 & $2.07 \pm 0.15 \mathrm{~b}$ & $1.56 \pm 0.13 b$ & $3.14 \pm 0.24 \mathrm{a}$ & $1.95 \pm 0.16 \mathrm{~b}$ & $3.10 \pm 0.57 \mathrm{a}$ & $2.80 \pm 0.33 \mathrm{a}$ & $3.60 \pm 0.22 \mathrm{a}$ & $2.60 \pm 0.40 \mathrm{a}$ \\
\hline DAT30 & $2.72 \pm 0.28 \mathrm{a}$ & $2.94 \pm 0.36 \mathrm{a}$ & $2.72 \pm 0.21 \mathrm{a}$ & $2.13 \pm 0.19 \mathrm{a}$ & $2.90 \pm 0.28 \mathrm{a}$ & $3.50 \pm 0.75 \mathrm{a}$ & $3.20 \pm 0.29 \mathrm{a}$ & $2.50 \pm 0.40 \mathrm{a}$ \\
\hline DAT45 & $2.86 \pm 0.42 \mathrm{c}$ & $4.53 \pm 0.35 \mathrm{a}$ & $3.70 \pm 0.50 \mathrm{ab}$ & $2.00 \pm 0.34 \mathrm{bc}$ & $2.60 \pm 0.31 \mathrm{ab}$ & $4.10 \pm 0.48 \mathrm{a}$ & $3.60 \pm 0.79 \mathrm{a}$ & $1.40 \pm 0.40 \mathrm{~b}$ \\
\hline DAT60 & $3.52 \pm 0.40 \mathrm{~b}$ & $5.21 \pm 0.35 \mathrm{a}$ & $4.58 \pm 0.42 \mathrm{ab}$ & $3.60 \pm 0.58 \mathrm{~b}$ & $3.50 \pm 0.54 \mathrm{a}$ & $3.60 \pm 0.34 \mathrm{a}$ & $3.10 \pm 0.43 \mathrm{ab}$ & $2.00 \pm 0.26 \mathrm{~b}$ \\
\hline DAT75 & $3.81 \pm 0.82 \mathrm{e}$ & - & $3.63 \pm 0.22 \mathrm{a}$ & $1.39 \pm 0.26 \mathrm{~b}$ & $2.80 \pm 0.44 \mathrm{~b}$ & - & $4.20 \pm 0.42 \mathrm{a}$ & $1.40 \pm 0.26 \mathrm{c}$ \\
\hline \multirow{2}{*}{ Time } & \multicolumn{4}{|c|}{ Number of roots } & \multicolumn{4}{|c|}{ Root length $(\mathrm{cm})$} \\
\hline & LHA & MHA & HHA & $\mathrm{CON}$ & LHA & MHA & HHA & $\mathrm{CON}$ \\
\hline DAT15 & $5.10 \pm 0.99 \mathrm{a}$ & $3.50 \pm 0.45 \mathrm{a}$ & $3.10 \pm 0.75 \mathrm{a}$ & $3.20 \pm 0.65 \mathrm{a}$ & $1.14 \pm 0.15 \mathrm{a}$ & $0.98 \pm 0.11 \mathrm{ab}$ & $0.57 \pm 0.12 \mathrm{c}$ & $0.71 \pm 0.15 b c$ \\
\hline DAT30 & $7.40 \pm 0.92 \mathrm{a}$ & $5.50 \pm 0.62 \mathrm{a}$ & $5.70 \pm 0.58 \mathrm{a}$ & $5.20 \pm 0.73 \mathrm{a}$ & $4.35 \pm 0.28 \mathrm{a}$ & $1.35 \pm 0.10 \mathrm{~b}$ & $1.34 \pm 0.12 \mathrm{~b}$ & $1.85 \pm 0.29 \mathrm{~b}$ \\
\hline DAT45 & $7.10 \pm 0.95 \mathrm{a}$ & $7.80 \pm 0.84 \mathrm{a}$ & $7.00 \pm 1.44 \mathrm{a}$ & $5.50 \pm 1.09 \mathrm{a}$ & $3.45 \pm 0.49 \mathrm{a}$ & $1.63 \pm 0.16 \mathrm{~b}$ & $1.53 \pm 0.29 \mathrm{~b}$ & $2.70 \pm 0.58 \mathrm{ab}$ \\
\hline DAT60 & $9.90 \pm 1.45 \mathrm{a}$ & $5.80 \pm 0.80 \mathrm{~b}$ & $7.20 \pm 0.65 \mathrm{ab}$ & $9.10 \pm 0.81 \mathrm{a}$ & $4.18 \pm 0.59 \mathrm{a}$ & $2.35 \pm 0.43 b$ & $2.01 \pm 0.29 \mathrm{~b}$ & $4.58 \pm 0.43 \mathrm{a}$ \\
\hline DAT75 & $14.50 \pm 1.65 \mathrm{a}$ & - & $9.00 \pm 0.87 \mathrm{~b}$ & $6.90 \pm 1.57 \mathrm{~b}$ & $5.75 \pm 0.34 \mathrm{a}$ & - & $3.19 \pm 0.36 \mathrm{~b}$ & $3.18 \pm 0.78 \mathrm{~b}$ \\
\hline \multirow{2}{*}{ Time } & \multicolumn{4}{|c|}{ FFresh bulblet weight (mg) } & \multicolumn{4}{|c|}{ Fresh plantlet weight (mg) } \\
\hline & LHA & MHA & HHA & $\mathrm{CON}$ & LHA & MHA & HHA & $\mathrm{CON}$ \\
\hline DAT15 & $108.00 \pm 0.95 \mathrm{a}$ & $93.00 \pm 1.40 \mathrm{a}$ & $130.00 \pm 2.03 a$ & $109.00 \pm 1.39 \mathrm{a}$ & $130.00 \pm 1.17 \mathrm{~b}$ & $111.00 \pm 1.64 \mathrm{~b}$ & $188.00 \pm 2.60 \mathrm{a}$ & $142.00 \pm 1.46 \mathrm{ab}$ \\
\hline DAT30 & $220.00 \pm 2.47 \mathrm{a}$ & $215.00 \pm 2.88 \mathrm{a}$ & $133.00 \pm 1.19 \mathrm{~b}$ & $159.00 \pm 1.75 \mathrm{ab}$ & $283.00 \pm 3.14 \mathrm{ab}$ & $315.00 \pm 5.50 \mathrm{a}$ & $186.00 \pm 1.75 \mathrm{~b}$ & $193.00 \pm 1.86 \mathrm{~b}$ \\
\hline DAT45 & $193.00 \pm 2.16 \mathrm{~b}$ & $267.00 \pm 2.32 \mathrm{a}$ & $174.00 \pm 2.43 b$ & $157.00 \pm 2.36 \mathrm{~b}$ & $254.00 \pm 2.68 b$ & $455.00 \pm 5.63 \mathrm{a}$ & $304.00 \pm 5.21 \mathrm{~b}$ & $185.00 \pm 2.50 \mathrm{~b}$ \\
\hline DAT60 & $344.00 \pm 3.48 \mathrm{a}$ & $294.00 \pm 2.75 \mathrm{a}$ & $263.00 \pm 2.73 a$ & $256.00 \pm 2.48 \mathrm{a}$ & $455.00 \pm 5.53 \mathrm{a}$ & $454.00 \pm 4.39 \mathrm{a}$ & $379.00 \pm 4.06 \mathrm{a}$ & $331.00 \pm 3.75 \mathrm{a}$ \\
\hline DAT75 & $468.00 \pm 6.29 \mathrm{a}$ & - & $286.00 \pm 2.13 b$ & $160.00 \pm 3.77 \mathrm{~b}$ & $593.00 \pm 1.10 \mathrm{a}$ & - & $379.00 \pm 2.98 \mathrm{ab}$ & $170.00 \pm 4.09 \mathrm{~b}$ \\
\hline \multirow{2}{*}{ Time } & \multicolumn{4}{|c|}{$\begin{array}{l}\text { Relative bulblet weight }(\%)^{Z} \\
\end{array}$} & \multicolumn{4}{|c|}{ Bulblet diameter $(\mathrm{mm})^{\mathrm{Y}}$} \\
\hline & LHA & MHA & HHA & $\mathrm{CON}$ & LHA & MHA & HHA & $\mathrm{CON}$ \\
\hline DAT15 & $83.58 \pm 1.60 \mathrm{ab}$ & $84.91 \pm 3.25 \mathrm{a}$ & $68.38 \pm 3.09 \mathrm{c}$ & $75.58 \pm 3.25 \mathrm{bc}$ & & & & \\
\hline DAT30 & $77.50 \pm 2.11 \mathrm{ab}$ & $71.79 \pm 3.47 \mathrm{~b}$ & $72.16 \pm 2.49 \mathrm{~b}$ & $81.76 \pm 1.81 \mathrm{a}$ & & & & \\
\hline DAT45 & $76.69 \pm 3.46 \mathrm{a}$ & $61.47 \pm 3.19 \mathrm{~b}$ & $61.53 \pm 5.10 \mathrm{~b}$ & $84.41 \pm 4.78 \mathrm{a}$ & & & & \\
\hline DAT60 & $78.22 \pm 3.71 \mathrm{a}$ & $65.62 \pm 2.83 \mathrm{~b}$ & $69.99 \pm 3.25 \mathrm{ab}$ & $78.37 \pm 2.81 \mathrm{a}$ & $10.14 \pm 0.58 \mathrm{a}$ & $9.23 \pm 0.50 \mathrm{a}$ & $8.66 \pm 0.55 \mathrm{a}$ & $8.81 \pm 0.44 \mathrm{a}$ \\
\hline DAT75 & $84.46 \pm 3.55 \mathrm{~b}$ & - & $75.90 \pm 1.78 \mathrm{c}$ & $96.19 \pm 2.02 \mathrm{a}$ & $11.68 \pm 0.77 \mathrm{a}$ & - & $9.47 \pm 0.59 \mathrm{~b}$ & $6.90 \pm 0.82 \mathrm{c}$ \\
\hline \multirow{2}{*}{ Time } & \multicolumn{4}{|c|}{ Bulblet size $\left(\mathrm{mm}^{3}\right)^{\mathrm{YX}}$} & & & & \\
\hline & LHA & MHA & HHA & $\mathrm{CON}$ & & & & \\
\hline \multicolumn{9}{|l|}{ DAT15 } \\
\hline \multicolumn{9}{|l|}{ DAT30 } \\
\hline \multicolumn{9}{|l|}{ DAT45 } \\
\hline \multicolumn{9}{|c|}{ DAT60 593.00 $\pm 101.41 \mathrm{a} 444.28 \pm 72.40 \mathrm{a} 377.41 \pm 69.23 \mathrm{a} 382.41 \pm 60.59 \mathrm{a}$} \\
\hline DAT75 & $933.17 \pm 173.08 \mathrm{a}$ & - & $493.70 \pm 98.01 \mathrm{~b}$ & $221.61 \pm 60.26 c$ & & & & \\
\hline
\end{tabular}

DAT: days after transplanting; LHA: low concentration HA; MHA: moderate concentration HA; HHA: high concentration HA. Data are presented as means \pm standard error of the mean (SEM) with $n=10$. Mean separation within rows by Duncan's multiple range test at $P \leq 0.05$ (lowercase letter) for each trait. ${ }^{\mathrm{Z}}$ Relative bulblet weight $(\%)=$ fresh bulblet weight/fresh plantlet weight $\times 100 \% .{ }^{\mathrm{Y}}$ Data only recorded at DAT60 and after. ${ }^{\mathrm{X}}$ Bulblet size $\left(\mathrm{mm}^{3}\right)=4 / 3 \pi r^{3}, r=1 / 2$ bulblet diameter

HHA during the whole development stages were $70.95 \%$ and $69.59 \%$, respectively. This phenomenon suggested that assimilates were utilized by up-ground vegetative growth especially for two higher HA treatments with the exception of LHA. LHA performed the best, resulting in an average bulblet yield of $468 \mathrm{mg}, 10.14 \mathrm{~mm}$ for diameter, and $933 \mathrm{~mm}^{3}$ for bulblet size at DAT75, 2.9-fold, 1.7-fold, and 4.2-fold, respectively, higher than those for the control. On the basis of bulblet swelling rate, it was high during P1, and a source-sink rebalance emerged at P2. Thereafter, it kept climbing to $8.27 \mathrm{mg} /($ plantlet $\cdot \mathrm{d})$ even at P4 (Fig. 3). At DAT60, the bulblet reached a mature status for HA treatments whereas some 
indexes collapsed at DAT75 for CON, i.e., fresh bulblet weight experienced a sudden decrease to $160 \mathrm{mg}$ (Table 1).

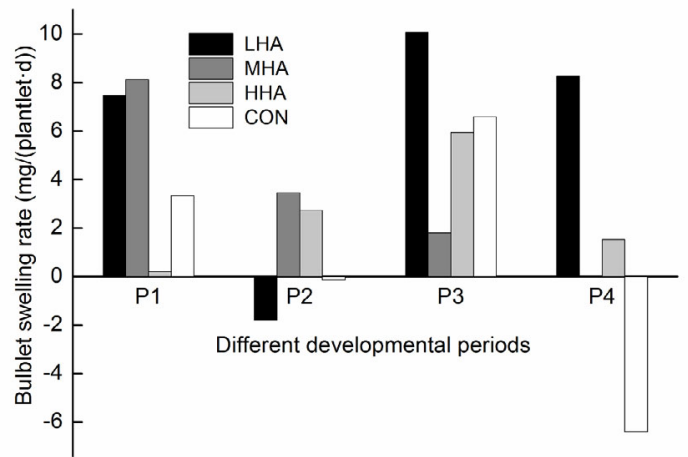

Fig. 3 Effects of humic acid (HA) on bulblet swelling rate during in vitro bulblet development of Lilium Oriental Hybrids 'Sorbonne'

P1, P2, P3, and P4 mean DAT15-DAT30, DAT30-DAT45, DAT45-DAT60, and DAT60-DAT75, respectively (DAT: days after transplanting)

\subsection{Dose-response curves and time course changes of HA on non-structural carbohydrate accumula- tion in vitro}

For the untreated control plants, the sucrose content changed steadily at around $8 \mathrm{mg} / \mathrm{g} \mathrm{FW}$, demonstrating that there is no evident substance transfer and utilization (Fig. 4a). When applied at moderate and higher concentrations ( $\geq 2 \mathrm{mg} / \mathrm{L}$ ), sucrose exerted a similar gradual increase during the bulblet growing stage, and for HHA, it peaked at $14.61 \mathrm{mg} / \mathrm{g} \mathrm{FW}$, indicating efficient sucrose unloading and storage, particularly from aboveground. These were consistent with the observations in plantlet height and number of leaves, most of which were much higher than those having both LHA and CON treatments (Table 1). However, $0.2 \mathrm{mg} / \mathrm{L} \mathrm{HA}$ had a relative low sucrose content compared with the other two HA treatments with two valley value at DAT15 (6.31 mg/g FW) and DAT60 (7.51 mg/g FW), which possibly meant that fast sucrose utilization and circulation was in progress. Total soluble sugar mainly consists of sucrose, fructose, maltose, glucose, etc. In the present study, it had almost the same trends as sucrose, only with greater values (Fig. 4b).

A promotive effect of HA application at early stage on starch enrichment was observed in all doses. From low to high HA concentrations, starch content was elevated by $15.3 \%, 31.0 \%$, and $16.8 \%$,
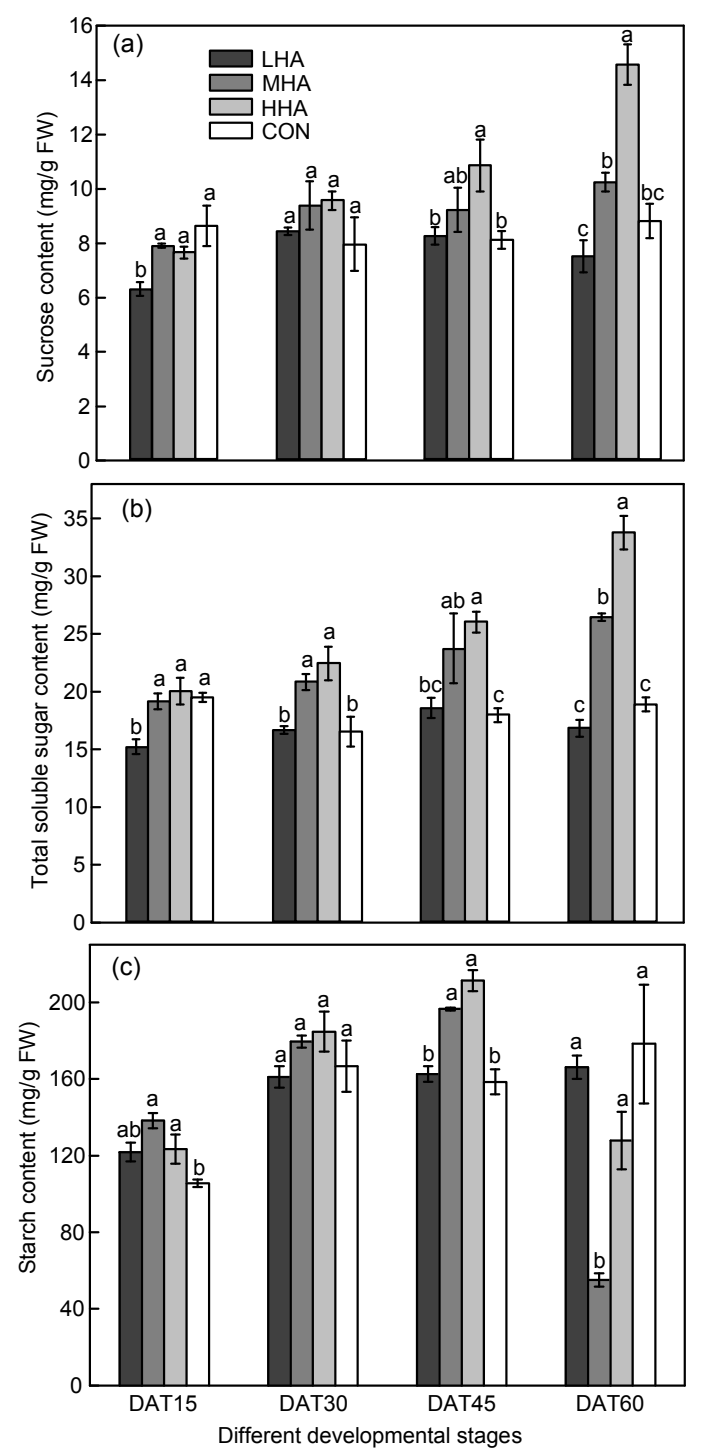

Fig. 4 Effects of humic acid (HA) on major non-structural carbohydrates during in vitro bulblet development of Lilium Oriental Hybrids 'Sorbonne'

The in vitro shoots were transplanted to medium containing basal MS plus $8 \mathrm{~g} / \mathrm{L}$ agar and $70 \mathrm{~g} / \mathrm{L}$ sucrose with different doses of HA, 0 (CON), 0.2 (LHA), 2.0 (MHA), and 20.0 (HHA) $\mathrm{mg} / \mathrm{L}$, respectively. For each treatment, 200 shoots were initially used. The bulblets were harvested at 9:00 a.m. on each sampling date. Data are means of three independent biological replicates. Push pin represents standard error $(n=10)$. Means within each column denoted by the same lowercase letter do not significantly differ at $P<0.05$ according to the Duncan test. DAT: days after transplanting. (a) Sucrose content; (b) Total soluble sugar content; (c) Starch content

respectively. A continuous increase of starch accumulated until DAT45, suggesting that carbon fixation happened progressively. For instance, starch content 
reached $211.42 \mathrm{mg} / \mathrm{g} \mathrm{FW}$ for HHA at DAT45, which was 1.3 -fold compared with the control. Accordingly, HA treatment could promote starch filling in a bulblet when carbon supply was sufficient in the medium in vitro. A slight increase in starch for LHA while a parallel collapse appeared for higher HA doses (Fig. 4c). The same phenomenon could be observed for LHA at DAT75. We found that starch for HHA $(216.12 \mathrm{mg} / \mathrm{g} \mathrm{FW})$ began to accumulate again after a rebalance of source-sink.

By calculating the starch accumulation rate, we found that HA treatments strengthened starch synthesis and degradation compared with $\mathrm{CON}$ while LHA had a relatively delayed response to carbon starvation (Fig. 5).

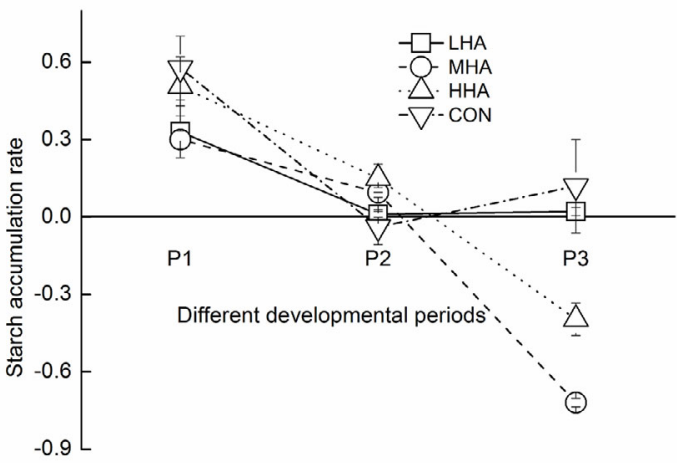

Fig. 5 Comparison of humic acid (HA) treatments to the starch accumulation rate of Lilium Oriental Hybrids 'Sorbonne' in vitro

Push pin represents standard error $(n=10)$. P1 represents DAT15-DAT30; P2 represents DAT30-DAT45; P3 represents DAT45-DAT60

\subsection{Dynamic changes of starch metabolism- related enzymes in lily bulblets in vitro}

At low concentrations $(0.2 \mathrm{mg} / \mathrm{L}), \mathrm{HA}$ treatment could enhance all the three enzyme activities very significantly to an extraordinarily high level of 29.4, 7.0, and $28.8 \mathrm{nmol} /(\mathrm{mg}$ protein $\cdot \mathrm{min})$ for AGPase, GBSS, and SSS at DAT15, respectively, which were higher than those in MHA by $150.54 \%, 112.40 \%$, and $120.63 \%$, respectively. AGPase thus persisted at $29.0 \mathrm{nmol} /(\mathrm{mg}$ protein $\cdot \mathrm{min})$ at DAT30 while both GBSS and SSS continually enhanced by 2.3 and 1.3 times, respectively. Thereafter, all the three enzymes showed a gradual decline until DAT60 (Fig. 6).

A similar tendency in enzyme activity was observed again for higher HA application (2.0 and $20.0 \mathrm{mg} / \mathrm{L}$ ). An inhibition emerged compared with

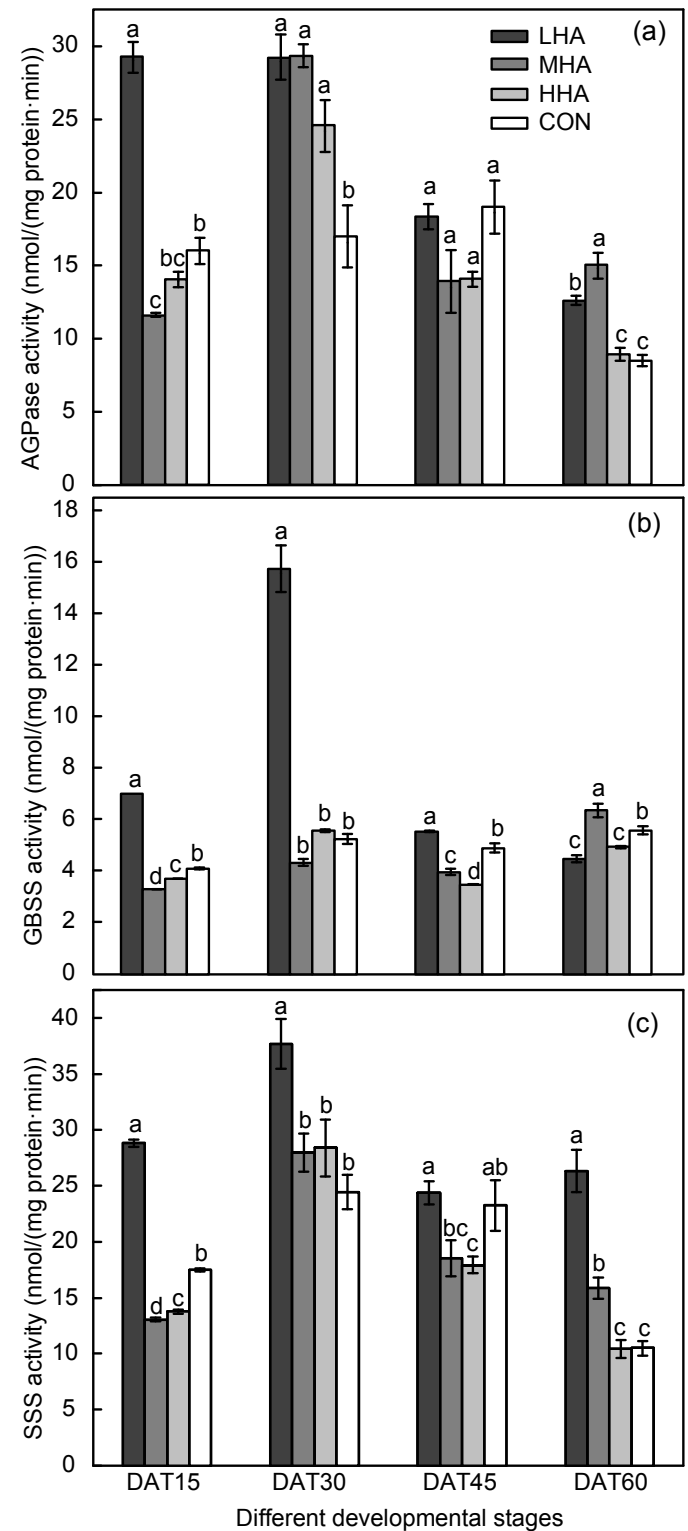

Fig. 6 The dose- and time-course response of humic acid (HA) on starch synthesizing enzyme activities during in vitro bulblet development of Lilium Oriental Hybrids 'Sorbonne'

The in vitro shoots were transplanted to a medium containing basal MS plus $8 \mathrm{~g} / \mathrm{L}$ agar and $70 \mathrm{~g} / \mathrm{L}$ sucrose with different doses of HA, 0 (CON), 0.2 (LHA), 2.0 (MHA), 20.0 (HHA) $\mathrm{mg} / \mathrm{L}$, respectively. For each treatment, 200 shoots were initially used. The bulblets were harvested at 9:00 a.m. on each sampling date. Data are means of three independent biological replicates. Push pin represents standard error $(n=10)$. Means within each column denoted by the same lowercase letter do not significantly differ at $P<0.05$ according to the Duncan test. DAT: days After Transplanting. (a) ADPG pyrophosphorylase (AGPase) activity; (b) Granule-bound starch synthase (GBSS) activity; (c) Soluble starch synthase (SSS) activity 
untreated control plants at DAT15, as opposed to the elevation in LHA. However, AGPase and SSS activities were rapidly elevated at DAT30, which apparently implied an accelerated starch metabolic pathway. Although we cannot precisely explain the reason for the lower starch enzyme activity with respect to the higher amount of starch at DAT15 for these two treatments, we assume that it might possibly be attributed to transitory starch transportation from leaf to bulblet and low starch break down enzymes. By contrast, GBSS changed little, and therefore, amylopectin may account for the greater proportion in higher HA treatment plants. For control plants, three enzymes changed relatively more stably, especially for AGPase and GBSS. Taking GBSS as an example, the values just held at around $4.09-5.57 \mathrm{nmol} /(\mathrm{mg}$ protein $\cdot \mathrm{min})$ (Fig. 6b).

\section{Discussion}

Reproduction of lily bulbs can be achieved through various approaches including tissue culture. The formation and development of bulblets are crucial in the life cycle (Li et al., 2014). Despite lots of literature on micropropagation of Lilium (Joshi and Dhar, 2009; Saadon and Zaccai, 2013), the physiological and biochemical mechanisms governing bulblet development remain unclear. Much evidence has shown that HA favors plant growth in many ways but is limitedly used in bulbous crops including in vitro. Lower molecular size fraction of HA, e.g. fulvic acid, can easily reach the plasmalemma of higher cells and therefore is the major candidate for determining the positive effects of HA on plant growth (Nardi et al., 2002). In our experiment, HA containing more than $90 \%$ fulvic acid was chosen, and the beneficial aspects were substantiated by the promotive effect especially at lower concentration.

We found that HA accelerated the aboveground leaves' growth to a different extent in lily (Table 1), which was in accordance with the previous report of HA treatments in cucumber (Mora et al., 2010). However, Adani et al. (1998) showed contradictory results in tomato plants using hydroponics culture. CP-A (commercially-available HA products prepared from peat) stimulated root growth only while having no impact on shoots at $20.0 \mathrm{mg} / \mathrm{L}$. The HA effect on shoot growth might be closely related to several fac- tors, e.g., species sensitivity, $\mathrm{pH}$ condition (de Kreij and Başar, 1995), HA origins (Adani et al., 1998), and medium containing $\mathrm{N}$ or not (Malik and Azam, 1985). Research has also shown that HA increased chlorophyll content which can accordingly strengthen photosynthesis (Xu, 1986; Liu et al., 1998). Sufficient mature functional leaves promoted photosynthesis (Zheng et al., 2012) during the day, and the fixed carbon, like sucrose, is transported from the photosynthetic apparatus to the non-photosynthetic organs during the night (Bahaji et al., 2014). That is, more vigorous leaves gave rise to sucrose accumulation.

Previous reports have demonstrated that HA can facilitate the plant rhizosphere environment and biological characteristics (Canellas et al., 2002). HA was applied to improve the post-rooting stage in American chestnut shoots with difficulty in rooting as tree species (Oakes et al., 2016). We also reported that $500 \mathrm{mg} / \mathrm{L} \mathrm{HA}$ combined with $7 \mathrm{mmol} / \mathrm{L} \mathrm{Ca}$ favored root growth in the Oriental lily 'Sorbonne' (Chang et al., 2012). For the in vitro lily, we observed that low HA produced more roots than $\mathrm{CON}$, e.g., to 14.5 at DAT75 for LHA (Table 1). However, higher HA concentrations $(\geq 2.0 \mathrm{mg} / \mathrm{L})$ showed an inhibitive effect on root length. In comparison, $0.2 \mathrm{mg} / \mathrm{L} \mathrm{HA}$ performed best both in root number and root length (Table 1). The huge difference in effective concentration between field and tissue culture might be due to two reasons: (1) iron-reducing, fermenting bacteria etc. in the soil may lead to HA reduction (Benz et al., 1998); (2) plantlets in vitro absorb HAs in the medium more directly. As such, we concluded that it is necessary to take the dose effect into consideration when using HA and that the in vitro condition is more sensitive. Too high HA may cause a repression effect, which was in line with results in tomato and cucumber (Atiyeh et al., 2002). Thus, in terms of shoot and roots traits, the effects were the reverse in LHA and higher HA treatments (Table 1). It was reported that the mechanism responsible for shoot growth of HA might be ascribed to the enhancement in root $\mathrm{H}^{+}$ATPase activity and the increase in nitrate shoot concentration, which in turn causes root-shoot distribution (Mora et al., 2010). Tao et al. (1987) used HAs by different application methods (spray, drench, and soaking) and various concentrations (50$300 \mathrm{ppm}(1 \mathrm{ppm}=1 \mathrm{mg} / \mathrm{L}))$. They found that $100 \mathrm{ppm}$ had the most effective result and that increased potato yield per mu ( $1 \mathrm{mu}=1 / 15 \mathrm{ha})$ by $11.4 \%$ to $33.5 \%$ 
compared with the control trial. The larger tuber held a much greater proportion in total tuber number and the small tuber was only $9.55 \%-22.1 \%$ that of control The weight of extra-large tubers increased in the fulvic acid treated potato (Suh et al., 2014). The bulblet size (weight and volume) was smaller for higher HA doses $(\geq 2.0 \mathrm{mg} / \mathrm{L})$ than for LHA. In terms of morphogenic traits only, two factors might be involved. Firstly, less robust roots would affect the carbon and nutrition absorption rate from the culture medium; secondly, excessive aboveground growth entailed extra energy and nutrition consumption. Although more leaves gained more photosynthesis, a relatively low average relative bulblet weight during the whole development process for MHA (70.95\%) and HHA $(69.59 \%)$ verified assimilates allocation between shoot (leaves) and root (bulblet) (Gerrits and de Klerk, 1992).

Intriguingly, a sharp decrease was found in fresh bulblet weight for CON at DAT75. In Lilium rubellum in vitro culture, three sugars (sucrose, glucose, and fructose) were detected in the autoclaved MS medium which only contained sucrose. Sugars in the $150 \mathrm{mmol} / \mathrm{L}$ (about $51.34 \mathrm{~g} / \mathrm{L}$ ) sucrose medium were nearly depleted by Week 8 , whereas those in the $250 \mathrm{mmol} / \mathrm{L}$ sucrose medium persisted for 12 weeks (Niimi et al., 2000). Similar sucrose depletion was observed during Lilium japonicum bulblet swelling (Yamagishi, 1998). Thus, it was certain that $70 \mathrm{~g} / \mathrm{L}$ had already been used up in the medium (carbon starvation) whilst the limited number of leaves (2) was not enough to produce carbon to support further growth both in the aboveground part and the bulblet. Carbohydrates are hypothesized to modulate expression of lily developmental genes, a phenomenon known as sugar sensing (Koch, 1996). Sucrose is required as the carbon source (Takayama and Misawa 1979) and serves as the primary transport carbohydrate in Lilium. In other words, sucrose is the end product of photosynthesis in leaves for translocation from the source (leaf) to heterotrophic sink (bulblet) through the phloem (Ruan, 2014) and can be utilized directly for plant growth. Accumulation of total soluble sugars was observed after exogenous HA application and sucrose was the dominant one (Figs. 4a and $4 \mathrm{~b}$ ). This was similar to the observation in the edible sweetpotato which had significantly increased soluble sugar content in storage organs (Liu et al., 2011). Use of vermicompost in garlic also corre- sponded to an increase in the total soluble carbohydrates (Argüello et al., 2006). In addition, soluble carbohydrates accumulated more with increase in HA doses in the present study (Fig. 4). Sucrose is not only the carbon source but also important for molecular signals (Koch, 2004). When sucrose is imported into the sink organ, it will be degraded into hexose or hexose phosphate to take part in cell metabolism or it will result in "sucrose accumulation". The degradation direction of sucrose determines the fate of assimilate utilization (Sonnewald and Uwe, 2012). Therefore, the relatively low sucrose content in LHA treatment was noticeable with two valley values at DAT15 and DAT60 (Fig. 4b). These were well correlated with the morphological traits including fresh bulblet weight since two vegetative growth peaks emerged at DAT15 and DAT60 for LHA, implying that sucrose was used not only for energy metabolism but also for storage metabolism during these two development stages (Sonnewald and Uwe, 2012).

Starch biosynthetic and degradative genes in higher plants show high conservation in their biological roles (Tetlow et al., 2004). Generally, three enzymes, including AGPase, GBSS, and SSS, were directly involved in starch synthesis (Smith et al., 1997). HA application enhanced starch accumulation with dose increase and this was confirmed by high starch synthetic enzymes activity. LHA exerted the highest AGPase, GBSS, and SSS activities (Fig. 6a). The elevated starch enzyme activity was in synchrony with the lowest sucrose content in LHA treatment which was presumably due to high sucrose use efficiency. Similar findings were obtained in PGRs' foliar spray treatment in lily bulbs during the full- and post-blossoming periods (Zheng et al., 2012). Also, AGPase reached a very high level at DAT15 compared with GBSS and SSS (Fig. 6a), which confirmed the precursor and substrate role of ADPG to fully support the further amylose and amylopectin synthesis (Cheng et al., 2015). Notably, despite high starch synthetic enzymes, starch content was lowest among HA treatments for LHA (Fig. 4c). It was previously demonstrated that HA application in sweetpotato significantly elevated $\alpha$-amylase and $\beta$-amylase activities by $11.33 \%$ and $15.70 \%$, respectively (Liu et al., 2011). Therefore, we proposed that for LHA both starch synthesis and degradation directions were extremely active. Also, at DAT60, an earlier decrease in starch was observed for MHA and HHA while 
LHA delayed the carbon famine (Fig. 4b). As mentioned above, carbon in the medium was totally depleted around DAT60. Hence, it was a necessity to hydrolyse the starch in the bulblets into soluble sugars supporting plantlets growth at DAT60, which was in line with the consecutive increased sucrose content at the very same time point (Fig. 4a). Thus, it was a source-sink rebalance and conversion process.

\section{Conclusions}

Bulbous plants greatly contribute to the world flower industry while understanding of bulb development is very limited and this produces a bottleneck in the improvement of propagation and the breeding programme of new bulbous cultivars. To interpret the mechanisms of bulb development, we examined bulbs in vitro and HA was first applied. A range of morphology indices were determined which showed either root or leaf growth was elevated compared with the control treatment depending on the HA concentrations used. A significant promotion in bulblet diameter and weight was obtained with no deformity in LHA. We investigated the major compounds and enzymes involved in the starch synthesis pathway combined with HA dose effects. The lowest sucrose contents whilst highest AGPase, GBSS, and SSS activities for LHA were all observed as early as DAT15, implying the high efficiency in carbon utilization and source-sink conversion. Higher concentrations of HA ( 2.0 and $20.0 \mathrm{mg} / \mathrm{L})$ facilitated both sucrose and starch accumulation during the growing stage as compared with the control plants. LHA was the better choice. The average fresh bulblet weight and diameter could reach $468 \mathrm{mg}$ and $11.68 \mathrm{~mm}$, respectively. HA treatments are promising for use as an organic substance in bulblet production as well as being without residue to the soil or the environment. However, the detailed mechanisms need further clarification by taking both amylase and photosynthesis traits into consideration.

\section{Compliance with ethics guidelines}

Yun WU, Yi-ping XIA, Jia-ping ZHANG, Fang DU, Lin ZHANG, Yi-di MA, and Hong ZHOU declare that they have no conflict of interest.

This article does not contain any studies with human or animal subjects performed by any of the authors.

\section{References}

Adani, F., Genevini, P., Zaccheo, P., et al., 1998. The effect of commercial humic acid on tomato plant growth and mineral nutrition. J. Plant Nutr., 21(3):561-575. http://dx.doi.org/10.1080/01904169809365424

Alderson, P., Rice, R., Wright, N., 1982. Towards the propagation of tulip in vitro. Acta Hortic., 131:39-48. http://dx.doi.org/10.17660/ActaHortic.1983.131.3

Argüello, J.A., Ledesma, A., Núñez, S.B., et al., 2006. Vermicompost effects on bulbing dynamics, nonstructural carbohydrate content, yield, and quality of 'Rosado paraguayo' garlic bulbs. HortScience, 41(3):589-592.

Ascough, G.D., Erwin, J.E., Staden, J.V., 2008. Reduced temperature, elevated sucrose, continuous light and gibberellic acid promote corm formation in Watsonia vanderspuyiae. Plant Cell Tissue Organ Cult., 95(3): 275-283. http://dx.doi.org/10.1007/s11240-008-9441-6

Atiyeh, R.M., Lee, S., Edwards, C.A., et al., 2002. The influence of humic acids derived from earthwormprocessed organic wastes on plant growth. Bioresourc. Technol., 84(1):7-14. http://dx.doi.org/10.1016/S0960-8524(02)00017-2

Bahaji, A., Li, J., Sánchez-Lópeza, A.M., et al., 2014. Starch biosynthesis, its regulation and biotechnological approaches to improve crop yields. Biotechnol. Adv., 32(1): 87-106.

http://dx.doi.org/10.1016/j.biotechadv.2013.06.006

Benschop, M., Kamenetsky, R., Le Nard, M., et al., 2010. The global flower bulb industry: production, utilization, research. In: Janick, J. (Ed.), Horticultural Reviews, Volume 36. John Wiley \& Sons, Inc., Hoboken, NJ, USA, p.1-115. http://dx.doi.org/10.1002/9780470527238.ch1

Benz, M., Schink, B., Brune, A., 1998. Humic acid reduction by Propionibacterium freudenreichii and other fermenting bacteria. Appl. Environ. Microbiol., 64(11):4507-4512.

Bradford, M.M., 1976. A rapid and sensitive method for the quantitation of microgram quantities of protein utilizing the principle of protein-dye binding. Anal. Biochem., 72(1):248-254. http://dx.doi.org/10.1016/0003-2697(76)90527-3

Canellas, L.P., Olivares, F.L., Okorokovafaçanha, A.L., et al., 2002. Humic acids isolated from earthworm compost enhance root elongation, lateral root emergence, and plasma membrane $\mathrm{H}^{+}$-ATPase activity in maize roots. Plant Physiol., 130(4):1951-1957. http://dx.doi.org/10.1104/pp.007088

Chang, L., Wu, Y., Xu, W.W., et al., 2012. Effects of calcium and humic acid treatment on the growth and nutrient uptake of Oriental lily. Afr. J. Biotechnol., 11(9):22182222. http://dx.doi.org/10.5897/AJB11.1633

Chang, L., Xiao, Y.M., She, L.F., et al., 2013. Analysis of gene expression and enzyme activities related to starch metabolism in Lycoris sprengeri bulbs of different sizes. Sci. Hortic.-Amsterdam, 161:118-124. http://dx.doi.org/10.1016/j.scienta.2013.07.005

Chen, J.J., Liu, M.C., Yanghsiu, H., 2000. Size of in vitro 
plantlets affects subsequent tuber production of acclimated calla lily. HortScience, 35(2):290-292.

Cheng, N., Zeng, X.F., Zheng, X.F., et al., 2015. Cloning and characterization of the genes encoding the small and large subunit of the ADP-glucose pyrophosphorylase in lotus (Nelumbo nucifera Gaertn). Acta Physiol. Plant., 37(1): 1734 . http://dx.doi.org/10.1007/s11738-014-1734-2

de Klerk, G.J., 2012. Micropropagation of bulbous crops: technology and present state. Floricult. Ornam. Biotechnol., 6:1-8.

de Kreij, C., Başar, H., 1995. Effect of humic substances in nutrient film technique on nutrient uptake. J. Plant Nutr., 18(4):793-802. http://dx.doi.org/10.1080/01904169509364938

Gerrits, M.M., de Klerk, G.J., 1992. Dry-matter partitioning between bulbs and leaves in plantlets of Lilium speciosum regenerated in vitro. Acta Bot. Neer., 41(4):461-468. http://dx.doi.org/10.1111/j.1438-8677.1992.tb00516.x

Hayes, M.H.B., Clapp, C.E., 2001. Humic substances: considerations of compositions, aspects of structure, and environmental influences. Soil Sci., 166(11):723-737. http://dx.doi.org/10.1097/00010694-200111000-00002

Jásik, J., de Klerk, G.J., 2006. Effect of methyl jasmonate on morphology and dormancy development in lily bulblets regenerated in vitro. J. Plant Growth Regul., 25(1):45-51. http://dx.doi.org/10.1007/s00344-005-0048-4

Joshi, S.K., Dhar, U., 2009. In vitro propagation from axenic explants of Lilium oxypetalum (D. Don) Baker, an endemic bulbous plant of high altitude Himalaya. Acta Physiol. Plant., 31(4):833-838. http://dx.doi.org/10.1007/s11738-009-0299-y

Katoh, A., Ashida, H., Kasajima, I., et al., 2015. Potato yield enhancement through intensification of sink and source performances. Breeding Sci., 65(1):77-84.

http://dx.doi.org/10.1270/jsbbs.65.77

Kawa, L., de Hertogh, A., 1992. Root physiology of ornamental flowering bulbs. In: Janick, J. (Ed.), Horticultural Reviews, Volume 14. John Wiley \& Sons, Inc., Oxford, UK, p.57-88.

http://dx.doi.org/10.1002/9780470650523.ch2

Koch, K.E., 1996. Carbohydrate-modulated gene expression in plants. Annu. Rev. Plant Physiol. Plant Mol. Biol., 47(1): 509-540. http://dx.doi.org/10.1146/annurev.arplant.47.1.509

Koch, K.E., 2004. Sucrose metabolism: regulatory mechanisms and pivotal roles in sugar sensing and plant development. Curr. Opin. Plant Biol., 7(3):235-246. http://dx.doi.org/10.1016/j.pbi.2004.03.014

Kuijpers, A.M., Langens-Gerrits, M., 1997. Propagation of tulip in vitro. Acta Hortic., 430:321-324. http://dx.doi.org/10.17660/ActaHortic.1997.430.49

Kumar, S., Kashyap, M., Sharma, D.R., 2005. In vitro regeneration and bulblet growth from lily bulbscale explants as affected by retardants, sucrose and irradiance. Biol. Plant., 49(4):629-632. http://dx.doi.org/10.1007/s10535-005-0064-z

Li, X.Y., Wang, C.X., Cheng, J.Y., et al., 2014. Transcriptome analysis of carbohydrate metabolism during bulblet formation and development in Lilium davidii var. unicolor. BMC Plant Biol., 14:358.

http://dx.doi.org/10.1186/s12870-014-0358-4

Liu, C.H., Cooper, R.J., Bowman, D.C., 1998. Humic acid application affects photosynthesis, root development, and nutrient content of creeping bentgrass. HortScience, 33(6): 1023-1025.

Liu, H.J., Li, Z.M., Shi, C.Y., et al., 2011. Physiological basis of improving soluble sugar content in sweetpotato for table use by humic acid application. Acta Agron. Sin., 37(4):711-716 (in Chinese). http://dx.doi.org/10.3724/SP.J.1006.2011.00711

Malik, K.A., Azam, F., 1985. Effect of humic acid on wheat (Triticum aestivum L.) seedling growth. Environ. Exp. Bot., 25(3):245-252. http://dx.doi.org/10.1016/0098-8472(85)90008-5

Marinangeli, P., Curvetto, N., 1997. Bulb quality and traumatic acid influence bulblet formation from scaling in Lilium species and hybrids. HortScience, 32(4):739-741.

McCready, R., Guggolz, J., Silviera, V., et al., 1950. Determination of starch and amylose in vegetables. Anal. Chem., 22(9):1156-1158. http://dx.doi.org/10.1021/ac60045a016

Mora, V., Bacaicoa, E., Zamarreñob, A.M., et al., 2010. Action of humic acid on promotion of cucumber shoot growth involves nitrate-related changes associated with the root-to-shoot distribution of cytokinins, polyamines and mineral nutrients. J. Plant Physiol., 167(8):633-642. http://dx.doi.org/10.1016/j.jplph.2009.11.018

Murashige, T., Skoog, F., 1962. A revised medium for rapid growth and bio assays with tobacco tissue cultures. Physiol. Plant., 15(3):473-497. http://dx.doi.org/10.1111/j.1399-3054.1962.tb08052.x

Nakamura, Y., Yuki, K., Park, S.Y., et al., 1989. Carbohydratemetabolism in the developing endosperm of rice grains. Plant Cell Physiol., 30(6):833-839.

Nardi, S., Pizzeghello, D., Muscolo, A., et al., 2002. Physiological effects of humic substances on higher plants. Soil Biol. Biochem., 34(11):1527-1536. http://dx.doi.org/10.1016/S0038-0717(02)00174-8

Nelson, O.E., Rines, H.W., 1962. Enzymtic deficiency in waxy mutant of maize. Biochem. Biophys. Res. Commun., 9(4): 297. http://dx.doi.org/10.1016/0006-291X(62)90043-8

Niimi, Y., Misaki, Y., Nakano, M., 2000. Production of commercial bulbs of Lilium rubellum Baker: changes in carbohydrates in bulblets and sugars of liquid medium during their culture. J. Jpn. Soc. Hortic. Sci., 69(2): 161-165. http://dx.doi.org/10.2503/jjshs.69.161

Oakes, A.D., Desmarais, T., Powell, W.A., et al., 2016. Improving rooting and shoot tip survival of micropropagated transgenic american chestnut shoots. HortScience, 51(2): 171-176.

Podwyszyńska, M., 2012. The mechanisms of in vitro storage organ formation in ornamental geophytes. Floricult. Ornam. Biotechnol., 6:9-23.

Ruan, Y.L., 2014. Sucrose metabolism: gateway to diverse carbon use and sugar signaling. Annu. Rev. Plant Biol., 65(1):33-67. http://dx.doi.org/10.1146/annurev-arplant-050213-040251 
Saadon, S., Zaccai, M., 2013. Lilium candidum bulblet and meristem development. In Vitro Cell. Dev. Biol.-Plant, 49(3):313-319. http://dx.doi.org/10.1007/s11627-013-9496-x

She, L.F., Xia, Y.P., Chang, L., et al., 2014. Biochemical and physiological responses of bulblets of Lycoris aurea to exogenously applied N-(2-chloro-4-pyridyl)-N1-phenylurea. J. Hortic. Sci. Biotechnol., 89(5):549-556.

Smith, A.M., Denyer, K., Martin, C., 1997. The synthesis of the starch granule. Annu. Rev. Plant Biol., 48(1):67-87. $\mathrm{http} / / / \mathrm{dx}$.doi.org/10.1146/annurev.arplant.48.1.67

Sonnewald, S.J.F., Uwe, S., 2012. The mode of sucrose degradation in potato tubers determines the fate of assimilate utilization. Fr. Plant Sci., 3:279-286. http://dx.doi.org/10.3389/fpls.2012.00023

Streb, S., Zeeman, S.C., 2012. Starch metabolism in Arabidopsis. Arabidopsis Book, 10:e160. http://dx.doi.org/10.1199/tab.0160

Suh, H.Y., Yoo, K.S., Suh, S.G., 2014. Tuber growth and quality of potato (Solanum tuberosum L.) as affected by foliar or soil application of fulvic and humic acids. Hortic. Environ. Biotechnol., 55(3):183-189. http://dx.doi.org/10.1007/s13580-014-0005-x

Takayama, S., Misawa, M., 1979. Differentiation in Lilium bulbscales grown in vitro. Effect of various cultural conditions. Physiol. Plant., 46(2):184-190. http://dx.doi.org/10.1111/j.1399-3054.1979.tb06555.x

Tao, Q.Z., Yang, D., Wu, Z.C., 1987. The researches on stimulation of humic acid to crops, II, the effects of humic acid on enhancing potato yield and quality. Humic Acid, 3:17-29 (in Chinese).

Tetlow, I.J., Morell, M.K., Emes, M.J., 2004. Recent developments in understanding the regulation of starch metabolism in higher plants. J. Exp. Bot., 55(406):21312145 .

http://dx.doi.org/10.1093/jxb/erh248

Thakur, R., Sood, A., Nagar, P.K., et al., 2006. Regulation of growth of Lilium plantlets in liquid medium by application of paclobutrazol or ancymidol, for its amenability in a bioreactor system: growth parameters. Plant Cell Rep., 25(5):382-391. http://dx.doi.org/10.1007/s00299-005-0094-1

Wang, R.J., Wang, Z.L., Liang, T.B., et al., 2008. Effects of HA-K fertilizers on the absorption and utilization of potassium and storage root yield in sweet potato for table use. Plant Nutr. Fert. Sci., 14(3):520-526 (in Chinese).

Wu, S.S., Chen, L.N., Zhang, Q.X., et al., 2012. Source and sink changes of lily bulb and the transportation role of the basal plate during the development of oriental hybrid lily 'Sorbonne'. J. Food Agric. Environ., 10(2):1213-1219.

Xiao, Y.M., She, L.F., Chang, L., et al., 2013. Effect of three plant growth regulators on the bulblets development of Lycoris radiata. J. Nuclear Agric. Sci., 27(9):1409-1415 (in Chinese).

Xu, X.D., 1986. The effect of foliar application of fulvic-acid on water-use, nutrient-uptake and yield in wheat. Aust. J. Agric. Res., 37(4):343-350. http://dx.doi.org/10.1071/AR9860343

Yamagishi, M., 1998. Effects of culture temperature on the enlargement, sugar uptake, starch accumulation, and respiration of in vitro bulblets of Lilium japonicum Thunb. Sci. Hortic.-Amsterdam, 73(4):239-247. http://dx.doi.org/10.1016/S0304-4238(97)00159-3

Zandonadi, D.B., Canellas, L.P., Facanha, A.R., 2007. Indolacetic and humic acids induce lateral root development through a concerted plasmalemma and tonoplast $\mathrm{H}^{+}$ pumps activation. Planta, 225(6):1583-1595. http://dx.doi.org/10.1007/s00425-006-0454-2

Zheng, R.R., Xia, Y.P., Sun, X.J., 2011. Uniconazole promotes carbohydrate accumulation in bulbs of Lilium Oriental hybrid 'Sorbonne'. Indian J. Hortic., 68(1):139-141.

Zheng, R.R., Wu, Y., Xia, Y.P., 2012. Chlorocholine chloride and paclobutrazol treatments promote carbohydrate accumulation in bulbs of Lilium Oriental hybrids 'Sorbonne'. J. Zhejiang Univ.-Sci. B (Biomed. \& Biotechnol.), 13(2):136-144.

http://dx.doi.org/10.1631/jzus.B1000425

\section{List of electronic supplementary materials}

Fig. S1 Classic interpretation of source-sink-conversion pathway in in vitro bulblet

\section{中文概要}

\section{题 目: 低浓度腐殖酸处理通过促进根系发育及碳水化合 物代谢促进百合离体小鳞茎膨大}

目 的: 小鳞茎发育问题研究是缩短百合育种周期、加快 百合种球产业化生产的关键, 而碳水化合物代谢 则是影响小鳞茎发育的重要因子。离体快繁技术 因更高效的繁殖速率及易控的环境条件, 是鳞茎 发育问题研究的替代途径, 但目前有关离体条件 下鳞茎发育机制研究鲜有报道。本文采用腐殖酸 处理东方百合 “索邦” , 研究其对于鳞茎膨大的 影响及碳水化合物代谢调控路径。

创新点: 本研究首次采用安全无残留型植物生长调节物质 腐殖酸处理, 并探讨了其对百合离体鳞茎发育的 有效影响及内在的碳水化合物代谢生理生化机 制。

方 法: 以构建的离体模式体系下形成的百合单芽, 接种 至含不同浓度腐殖酸 ( $0 、 0.2 、 2.0$ 和 $20.0 \mathrm{mg} / \mathrm{L})$ 的培养基上, 每隔 15 天取样一次, 测定株高等 7 个形态指标; 同时，取鳞茎测定主要非结构性碳 水化合物 (蔗糖、可溶性糖、淀粉) 含量及关键 淀粉合成酶（AGPase、SSS 和 GBSS）活性。

结论: 随腐殖酸处理浓度升高, 相对鳞茎重量下降, 从 而打破库一源平衡, 低浓度腐殖酸 $(0.2 \mathrm{mg} / \mathrm{L})$ 处 理效果最佳, 鳞茎重量为 $468 \mathrm{mg}$ (为对照的 2.9 倍）, 鳞茎直径达 $11.68 \mathrm{~mm}$ 。具体来说, 低浓度 腐殖酸处理可促进根系发育, 并在发育早期大幅 促进淀粉合成相关酶活性, 并通过加速蔗糖/淀粉 利用及转换延缓了碳饥饿出现时间。

关键词: 小鳞茎发育; 腐殖酸; 淀粉代谢; 库一源转换; 东方百合 “索邦” 